\title{
Wavelet deconvolution technique for impact force reconstruction: mutual deconvolution approach
}

\author{
Hai Tran ${ }^{1,2, *}$, Tat-Hien Le ${ }^{1,2}$
}

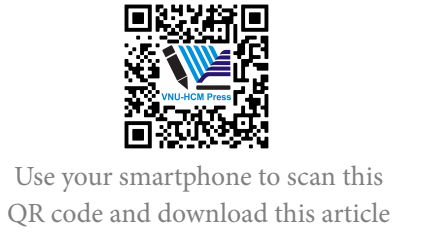

${ }^{1}$ Ho Chi Minh City University of

Technology, Vietnam

${ }^{2}$ Vietnam National University Ho Chi

Minh City, Vietnam

Correspondence

Hai Tran, Ho Chi Minh City University of Technology, Vietnam

Vietnam National University Ho Chi Minh City, Vietnam

Email: haitran@hcmut.edu.vn

History

- Received: 19-7-2019

- Accepted: 30-12-2020

- Published: 11-02-2021

DOI : 10.32508/stdjet.v3iSI2.507

\section{Check for updates}

Copyright

(c) VNU-HCM Press. This is an openaccess article distributed under the terms of the Creative Commons Attribution 4.0 International license.

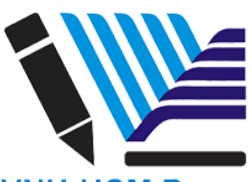

VNU-HCM Press

\begin{abstract}
In the field of impact engineering, one of the most concerned issues is how to exactly know the history of impact force which often difficult or impossible to be measured directly. In reality, information of impact force apply to structure can be identified by means of indirect method from using information of corresponding output responses measured on structure. Namely, by using the output responses (caused by the unknown impact force) such as acceleration, displacement, or strain, etc. in cooperation with the impulse response function, the profile of unknown impact force can be rebuilt. A such indirect method is well known as impact force reconstruction or impact force deconvolution technique. Unfortunately, a simple deconvolution technique for reconstructing impact force has often encountered difficulty due to the ill-posed nature of inversion. Deconvolution technique thus often results in unexpected reconstruction of impact force with the influences of unavoidable errors which is often magnified to a large value in reconstructed result. This large magnification of errors dominates profile of desired impact force. Although there have been some regularization methods in order to improve this ill-posed problem so far, most of these regularizations are considered in the whole-time domain, and this may make the reconstruction inefficient and inaccurate because impact force is normally limited to some portions of impact duration. This work is concerned with the development of deconvolution technique using wavelets transform. Based on the advantages of wavelets (i.e., localized in time and the possibility to be analyzed at different scales and shifts), the mutual reconstruction process is proposed and formulated by considering different scales of wavelets. The experiment is conducted to verify the proposed technique. Results demonstrated the robustness of the present technique when reconstructing impact force with more stability and higher accuracy.
\end{abstract}

Key words: Deconvolution, Impact force, Inverse analysis, Reconstruction, Wavelet transform

\section{INTRODUCTION}

Identification or measurement of impact force applying on structures has been considered as one of the essential issues in the field of impact engineering because the important information of impact force is really necessary for structural design process or evaluating impact behavior of structure during collisions. However, direct measurement of impact force is either rather difficult or even impossible except for some special cases. To address such difficulty, indirect measurement method or inverse or deconvolution methods have widely been used and developed in order to reconstruct or estimate impact force from its output response (e.g., strain, displacement, acceleration, etc.) along with the impact characteristic of structure $^{1}$. Basically, if the impact response at a certain location on the structure can be considered linearly dependent to impact force, the relationship between such impact response and impact force can be expressed by linear convolution. Therefore, theoretically, if the impact response can be measured and the impulse response function can also be known in advance, impact force can be estimated by solving this convolution. Unfortunately, deconvolution for reconstructing impact force often encounters the ill-posed nature of the inverse analysis, and as such, it often leads to an unstable reconstruction. Thus, many techniques have been utilized to deal with the ill-posedness in order to obtain a more stable estimation.

So far, in seeking a more robust deconvolution technique for impact force reconstruction, deconvolution in the wavelet domain using wavelet transform has been taken into account due to the advantages of wavelets such as localized in time, possibility to represent a signal at different scales and translations. Since the impact force is often finite in reality, the use of wavelets seems to be preferable and promising ${ }^{1}$. Doyle et al. ${ }^{2}$ used wavelets by only shifting without scaling, Inoue et al. ${ }^{3}$ utilized Gabor, Lifschitz et al. ${ }^{4}$ and Li et al. ${ }^{5}$ applied multiple resolution analysis of wavelets. Recently, Tran and Inoue ${ }^{6,7}$ devel- 
oped and verified the deconvolution technique with wavelet transform approach by numerical simulation. Although deconvolution technique with wavelets has been affirmed to be effective in estimating impact force, the ill-posed nature still exists and affects the reconstructed result. Thus, this paper proposed a mutual deconvolution technique, in which scale components of wavelets is considered as the regularization method in order to achieve a more robust approach for force reconstruction.

\section{MUTUAL DECONVOLUTION TECHNIQUE USING WAVELETS}

Basic knowledge of reconstructing impact force by deconvolution technique

When an arbitrary structure is subjected to an impact force $f(t)$, if the induced response $e(t)$ at a particular position on this structure linearly depends on the force, the relationship between this force and response can be represented by the following convolution integral

$$
e(t)=\int_{0}^{t} h(\tau) f(t-\tau) d \tau,
$$

where $h(t)$ is the impulse response function (IRF) which characterizes impact behavior of the system. It is assumed that $h(t)=f(t)=0$ for $t<0$. Suppose that there is the reference force $\bar{f}(t)$ also applying on this structure, and this reference force induces the reference response $\bar{e}(t)$. The mutual deconvolution can be formed according to $\mathrm{E}$. Wu et al. ${ }^{8}$ as follows

$$
\int_{0}^{t} \bar{e}(t) f(t-\tau) d \tau=\int_{0}^{t} e(t) \bar{f}(t-\tau) d \tau .
$$

Obviously, with three known quantities, namely the reference force $\bar{f}(t)$, the reference response $\bar{e}(t)$ (these two values can be obtained by calibration or numerical analysis), and the measured response $e(t)$, the impact force $f(t)$ can be estimated by Eq. (2).

\section{Wavelet expansion of impact force}

According to the theory of discrete wavelet transform $^{9}$, the impact force $f(t)$ can be expanded into its time-frequency components as

$$
\begin{aligned}
f(t) & =\sum_{m=m_{0}}^{M} \sum_{n=n_{0}}^{N_{m}} \widetilde{f}_{m, n}^{d} \psi_{m, n}(t) \\
& +\sum_{n=n_{0}}^{N_{M}} \widetilde{f}_{M, n}^{a} \varphi_{M, n}(t),
\end{aligned}
$$

of which

$$
\psi_{m, n}(t)=a_{0}^{-m / 2} \psi\left[\left(t-n b_{0} a_{0}^{m}\right) / a_{0}^{m}\right]
$$

and

$$
\varphi_{M, n}(t)=a_{0}^{-M / 2} \varphi\left[\left(t-n b_{0} a_{0}^{M}\right) / a_{0}^{M}\right]
$$

are the dilated and translated versions of the wavelet function $\psi(t)$ and the scaling function $\varphi(t)$, respectively, in which $a_{0}^{-m / 2}$ is a normalization constant, $a_{0}^{-m}$ and $n b_{0} a_{0}^{m}$ represent the dilation and translation parameters, respectively; $m\left(m_{0} \leq m \leq M\right)$ and $n\left(n_{0} \leq n \leq N_{M}\right)$ are integers. $\tilde{f}_{m, n}^{d}$ and $\widetilde{f}_{M, n}^{a}$ are respectively the expansion coefficients at a certain dilation level $m$ and $M$; the superscripts $d$ and $a$ denote the detail and approximation terms, respectively. For more detail, reader can refer to Tran and Inoue ${ }^{7}$.

\section{Mutual deconvolution with wavelets}

Letting the right-hand side of Eq. (2) is , then substituting $f(t)$ in Eq. (3) into the left-hand side of Eq. (2), we yield

$$
\begin{aligned}
& \sum_{m=m_{0}}^{M} \sum_{n=n_{0}}^{N_{m}} \widetilde{f}_{m, n}^{d} \alpha_{m, n}(t) \\
& +\sum_{n=n_{0}}^{N_{M}} \widetilde{f}_{M, n}^{a} \beta_{M, n}(t)=g(t),
\end{aligned}
$$

where

$$
\begin{aligned}
& \alpha_{m, n}(t)=\int_{0}^{t} \bar{e}(t) \psi_{m, n}(t-\tau) d \tau \\
& \beta_{m, n}(t)=\int_{0}^{t} \bar{e}(t) \psi_{M, n}(t-\tau) d \tau
\end{aligned}
$$

Discretizing the time variable as $t=k V t$ and using the vector and matrix representations for Eqs. (3) and (6), we can write

$$
\begin{aligned}
& \{f\}=[\psi]\{\tilde{f}\} \\
& \{g\}=[A]\{\tilde{f}\},
\end{aligned}
$$

in which $\{f\}$ and $\{g\}$ are column vectors composed of $f(k \triangle t)$ and $g(k \triangle t)$, respectively, with row index $k ;\{\tilde{f}\}$ is a column vector whose elements are $\widetilde{f}_{m, n}^{d}$ and $\widetilde{f}_{M, n}^{a}$ with row indices $m, n ;[\psi]$ is a matrix composed of $\psi_{m, n}(k \triangle t)$ and $\varphi_{M, n}(k \triangle t)$ with row index $k$ and column indices $m, n$; while the matrix $[A]$ consists of $\alpha_{m, n}(k \triangle t)$ and $\beta_{M, n}(k \triangle t)$ with row index $k$ and column indices $m, n$ as

$$
\begin{aligned}
& {[A]=} \\
& {\left[\left\{\alpha_{m_{0}, n_{0}}\right\} \ldots\left\{\alpha_{m_{0}, N_{0}}\right\} \ldots\left\{\alpha_{M, N_{M}}\right\}\left\{\beta_{M, n}\right\}\right]}
\end{aligned}
$$

Eliminating $\{\tilde{f}\}$ from Eq. (9), the impact force can be reconstructed by following equation

$$
\{f\}=[\psi][A]^{+}\{g\},
$$

where + denotes the Moore-Penrose generalized inverse. According to Eq. (12), the impact force $f(k \triangle t)$ can be reconstructed from experimental data $\bar{f}(k \triangle t)$, $\bar{e}(k \triangle t)$, and $e(k \triangle t)$. 
In practice, it is possible to measure several responses which are very useful for reconstruction of impact force $^{8}$. In this regard, Eq. (10) can be rewritten as

$$
\left\{\begin{array}{c}
\left\{g_{1}\right\} \\
\left\{g_{2}\right\} \\
\vdots \\
\left\{g_{L}\right\}
\end{array}\right\}=\left[\begin{array}{c}
{\left[A_{1}\right]} \\
{\left[A_{2}\right]} \\
\vdots \\
{\left[A_{L}\right]}
\end{array}\right]\{\tilde{f}\},
$$

in which $\left\{g_{1}\right\},\left\{g_{2}\right\}, \ldots,\left\{g_{L}\right\}$ and $\left[A_{1}\right],\left[A_{2}\right], \ldots,\left[A_{L}\right]$ are yielded by different responses measured at different locations. The reconstruction of impact force in Eq. (12) can be rewritten by the following Eq. (14)

$$
\{f\}=[\psi]\left\{\begin{array}{c}
\left\{g_{1}\right\} \\
\left\{g_{2}\right\} \\
\vdots \\
\left\{g_{L}\right\}
\end{array}\right\}\left[\begin{array}{c}
{\left[A_{1}\right]} \\
{\left[A_{2}\right]} \\
\vdots \\
{\left[A_{L}\right]}
\end{array}\right] .
$$

Regularization of wavelet deconvolution based on considering scaling and shifting components

The success of reconstructing $\{f\}$ in Eq. (12) depends on the ill-posed condition of the matrix which is obtained by Eqs. (7) and (8). In this work, this matrix is carefully considered by using different scales $(m)$ and shifts $(n)$ of wavelets with the hope that the optimal scale, as well as the optimal shifts, are properly chosen so as to mitigate the ill-posedness as much as possible. Namely, the matrix $[A]$ has to be regularized by controlling its components $\left(\alpha_{m, n}\right.$ and $\left.\beta_{M, n}\right)$, and as seen in Eqs. (7) and (8), these components can be controlled by means of controlling the components $\psi_{m, n}$ and $\varphi_{M, n}$ of the matrix. This matrix $[\psi]$ presented in these above equations is clearly written as Eq. (15). After considering to remove some small scales, i.e., when the first smallest scale is removed, all column components of the matrix $[\psi]$ at this scale in Eq. (15) is replaced by zeros as highlighted by the dash-red rectangular in Eq. (16)

If we want to remove other different scales, in the similar manner, all columns components at these scales will be replaced by zeros. This process continuously starts from the smallest scale to the largest scale. In fact, by eliminating some small scales, high-frequency components, oscillation, or unavoidable errors included in measurement data $(\bar{e})$ may be excluded or restricted when forming the matrix $[A]$. This may improve the ill-posedness of the matrix when taking its inversion in order to obtain the reconstruction of impact force according to Eqs. (12) or (14).

\section{EXPERIMENTAL RESULTS AND DISCUSSIONS}

\section{Experiment description}

The experiment is conducted to reconstruct the impact force which is produced by the rubber ball acting on the polycarbonate plate in order to validate the effectiveness of the wavelet deconvolution technique and show its advantages when considering regularization with scale components of wavelets. For further information of wavelets, reader can see the explanation of the scales and shifts of the wavelets as shown in Figure 5. The experiment is presented by Figure 2. In addition, in order to employ the proposed technique, Haar wavelet is chosen as mother wavelets in this work. The characteristics of the Haar wavelets is fully described by I. Daubechies? .

\section{Reconstruction of impact force}

In order to reconstruct the impact force produced by impact of the rubber ball to the polycarbonate plate, we need to know the reference force and reference response in advance. In this work, we use the impact hammer to apply the impact force (it is known), and measure the corresponding response of the polycarbonate plate simultaneously. After that, the impact hammer will be replaced by the rubber ball to apply different impact forces (unknown and need to be reconstructed) to the plate. Similarly, the impact responses will also be measured by strain gauges, and this impact response data will be utilized to reconstruct the cause -impact force.

As well known that combination of multiple responses measured from different locations may provide adequate impact information. Therefore, the use of single and multiple responses for the proposed approach is also investigated in this research.

\section{Using single response}

Only response measured by strain gauge \# 1 is used to reconstruct the impact force by means of the mutual wavelet deconvolution technique. Results are shown in Figure 3. First of all, the reconstruction of impact force applied on the plate without considering scales of wavelets is shown in Figure 3(a). Although the peak force may be observed, this reconstruction is unstable and not an expected result when it is extremely affected by the magnification of errors.

After applying the regularization by removing the first smallest scale (remove scale $m=1$ ), the reconstruction if figured out in Figure 3(b). Clearly, this reconstruction is more stable, and significantly improved 


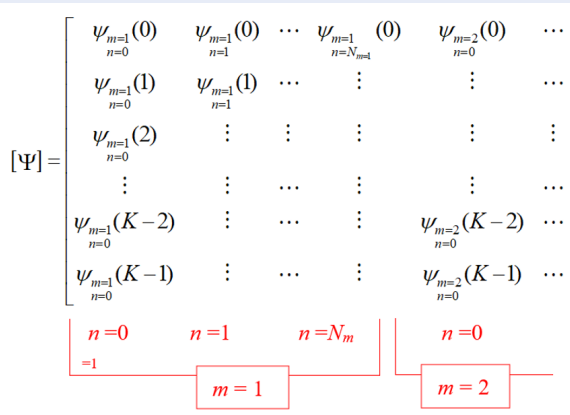

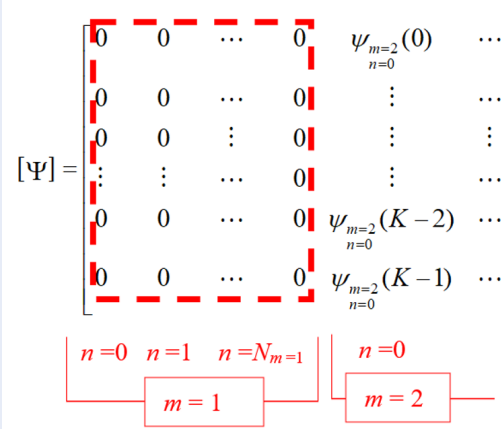

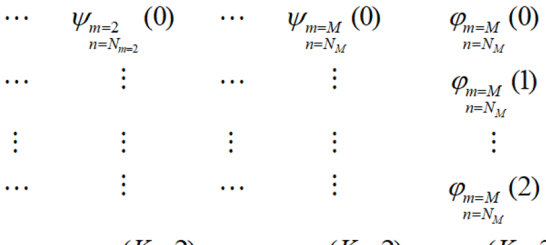

$$
\begin{aligned}
& \cdots \quad \psi_{\substack{m=2 \\
n=N_{m=2}}}(K-2) \quad \cdots \quad \psi_{\substack{m=M \\
n=N_{M}}}(K-2) \quad \varphi_{\substack{m=M \\
n=N_{M}}}(K-2) \\
& \left.\cdots \quad \psi_{\substack{m=2 \\
n=N_{m=2}}}(K-1) \quad \cdots \quad \psi_{\substack{m=M \\
n=N_{M}}}(K-1) \quad \varphi_{\substack{m=M \\
n=N_{M}}}(K-1)\right]
\end{aligned}
$$
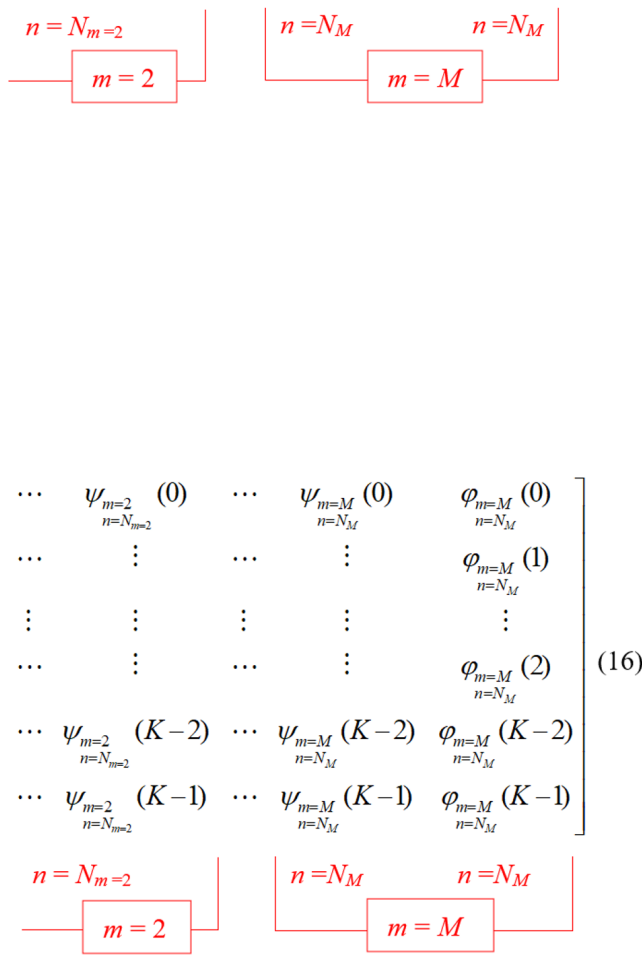

Figure 1: Equation (15) and equation (16) 


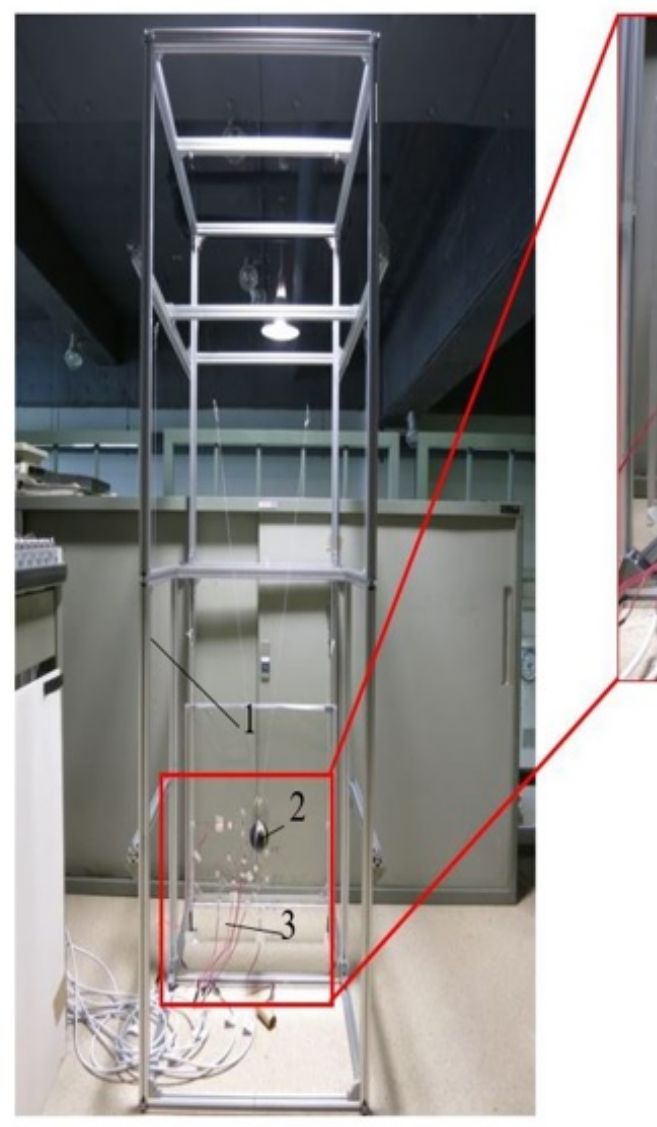

1. Aluminum frame

2. Impactor-rubber ball

3. Strain gauge to measure impact response

4. Polycarbonate plate

Figure 2: Experiment of impact between the rubber ball and polycarbonate plate.

in comparison with Figure 3(a). The magnification of errors is almost suppressed. This means that the consideration of eliminating the smallest scale mitigates the ill-posedness nature of the deconvolution problem remarkably. In the similar manner, removing the second and the third scales also provides a good reconstruction as seen in Figure 3(c) and (d), respectively. This is an evidence for the effectiveness of the proposed technique under consideration of scales of wavelets as regularization.

However, when removing to many scales, reconstructed result becomes more rough. This can be seen through Figs. 3(c) and (d). Thus, the optimal scales should be chosen carefully for reconstruction. In addition, in Figure 3, the reconstruction of impact force at the time after $4 \mathrm{~ms}$ may be incorrect. In fact, after reaching the peak value, the impact force will reduce gradually to zero. This incorrect reconstruction should be due to the lack or incorrection of impact information which is recorded by strain gauge \#1. This can be explained by the stress wave propagation from the impact location to the measurement location. In order to avoid this lack of impact information, combining various locations/multiple responses is suggested.

\section{Using multiple response}

In this part, instead of using response measured by strain gauge \#1, a combination of two responses measured by strain gauge \#1 and \#2 will be applied for reconstruction. Figure 3 shows the reconstruction of impact force when the rubber ball acting on the plate at $150 \mathrm{~mm}$ height. Namely, Figure 4(a) shows the reconstruction without applying regularization (no small scale is removed), meanwhile, Figure 4(b) and (c) indicate the reconstruction with applying the proposed regularization method. As seen in Figure 4(a), without applying the regularization, the reconstruction is unstable and noisy. This unstable reconstruction should due to the ill-posed problem as men- 


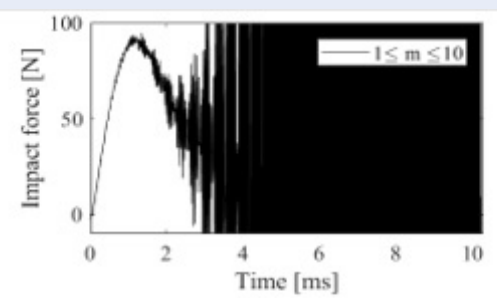

(a)

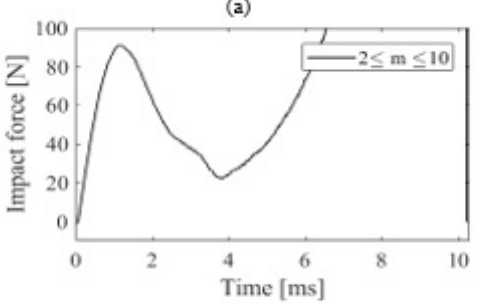

(b)

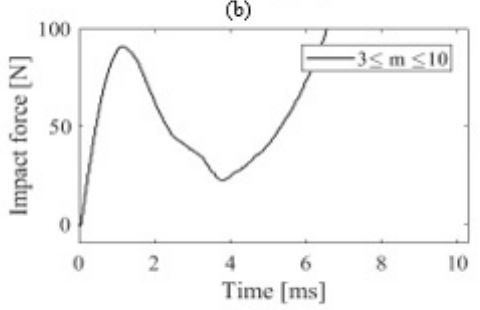

(c)

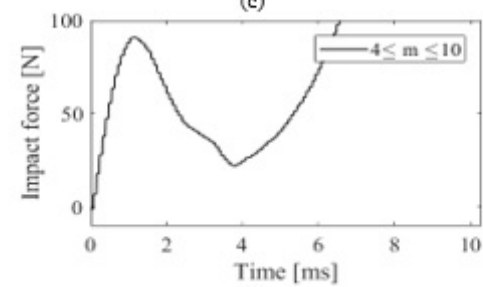

(d)

Figure 3: Reconstruction using single response \#1 without and with consideration of regularization

tioned above. Consequently, the impact force is reconstructed inaccurately.

By considering to remove the first smallest scales $(\mathrm{m}=1)$, reconstruction is more stable as seen in Figure 4(b). Comparing between Figure 4(a) and (b), it is easy to observe that applying the regularization with considering to eliminate the small scale, reconstruction is more accurate, and the magnification of errors is significantly suppressed. Nevertheless, the magnification of errors in reconstructed result still occurs after $5 \mathrm{~ms}$ of impact time. This remaining magnification of errors mostly appears at the time when the impact force is zero, so it can be ignored in reality.

Next, we try to remove the second smallest scale (both $\mathrm{m}=1$ and $\mathrm{m}=2$ ) with the hope that it will improve the accuracy and the stability of the reconstruction as much as possible. In this regard, after removing several scales corresponding to $\mathrm{m}=1, \mathrm{~m}=2$, and $\mathrm{m}=3$, the
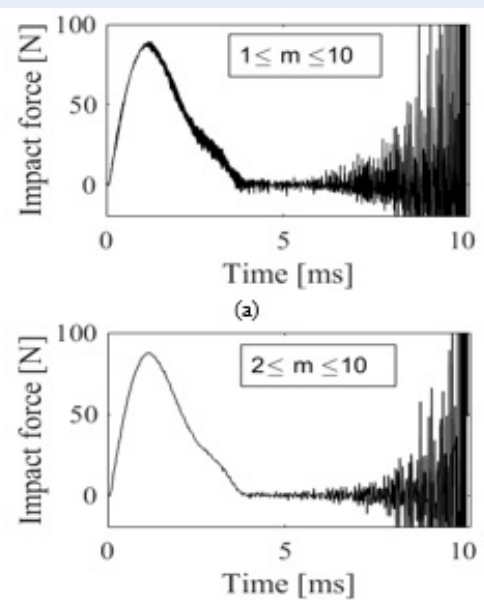

(b)

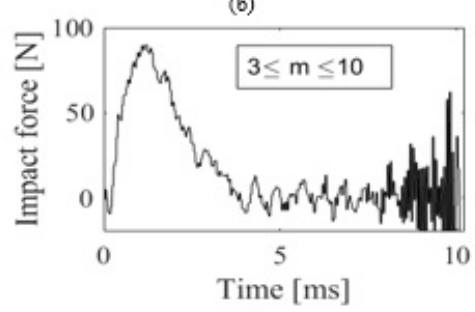

(c)

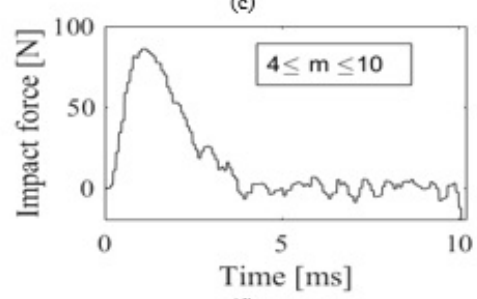

(d)

Figure 4: Reconstruction by combining multiple responses \#1 and \#2 without and with consideration of regularization.

reconstruction is less dominated by noise as shown in Figs. 3(c) and (d). Unfortunately, the results shown in Figs. 3(c) and (d) seem more coarse and less accurate than those in Figure 4(b) especially at the peak force. This inaccurate reconstruction should be due to the excessive loss of important information which is ignored during the reconstruction process when removing too many scales of wavelets. For more detail of considering the optimal scales, one can refer to Tran and Inoue ${ }^{7}$.

Comparing the results in Figure 4 and those in Figure 3, one can realize that the reconstruction using two responses is much better than using single response. Therefore, the proposed technique is also recommended to use with several responses. 


\section{CONCLUSION}

This paper developed and successfully applied the mutual deconvolution technique using wavelet approach for impact force reconstruction. The effectiveness of the present technique in mitigating the ill-posed nature of deconvolution problem has been demonstrated when considering the scale components of wavelets, and as such, the impact force is accurately and stably reconstructed.

\section{APPENDIX}

The WT is actually the projection of the original time signal $f(t)$ onto the basis of functions $\psi_{u, j}(t)$ defined by the dilations (scales)- $\mathrm{u}$ and transitions (shifts) $\mathrm{j}$ of the original wavelet function $\psi(t)$. In which the wavelet function $\psi(t)$ is called as mother wavelet function with zero average, or in other words, it satisfies the following admissibility condition

$$
\int_{-\infty}^{+\infty} \psi(t) d t=0
$$

When considering the dilations $(u)$ and translations $(j)$, this wavelet function is expressed as follows

$$
\psi_{u, j}(t)=\frac{1}{\sqrt{u}} \psi\left(\frac{t-j}{u}\right) .
$$

Therefore, the WT of an arbitrary signal or function or operator can be expressed by the following mathematical equation

$$
\widetilde{f}_{u, i}=\int_{-\infty}^{+\infty} f(t) \overline{\psi_{u, j}(t)} d t .
$$

By restricting $u, j$ to only discrete values as $u=$ $u_{0}^{m}\left(u_{0}>1\right)$ and $j=n j_{0} u_{0}^{m}\left(j_{0}>0\right), m$ and $n$ are integers, hence, the wavelet function and wavelet transform in Eqs. (17) and (18) become

$$
\left\{\psi_{m, n}(t)=\frac{1}{u_{0}^{m / 2}} \psi\left(\frac{t-n j_{0} u_{0}^{m}}{u_{0}^{m}}\right)\right\}_{(m, n) \in Z^{2}}
$$

and

$$
\widetilde{f}_{m, n}=u_{0}^{m / 2} \int_{-\infty}^{+\infty} f(t) \psi\left(u_{0}^{-m} t-n j_{0}\right) d t .
$$

As well known, in contrast to sinusoid functions used in Fourier transform, wavelets are not periodic and therefore it may be better to represent the signals with rapid changes.

\section{ACKNOWLEDGMENT}

This research is funded by Ho Chi Minh City University of Technology - VNUHCM, under grant number T-KTGT-2018-95. Authors would like to thank to Professor Inoue Hirotsugu, Assoc. Sakaguchi Motoki, and Dr. Kurokawa Yu, Department of Mechanical Engineering, Tokyo Institute of Technology, Japan, for their support and advice.

\section{AUTHORS' CONTRIBUTION}

Dr. Hai Tran presented the idea of research, carried out the experiment, collecting, analyzing experimental data, and writing the manuscript. Dr.Tat-Hien Le participated in the scientific idea of the research.

\section{CONFLICT OF INTEREST}

We declare that there is no conflict of whatsoever involved in publishing this research.

\section{REFERENCES}

1. Inoue H, Harrigan JJ, Reid SR. Review of inverse analysis for indirect measurement of impact force. Appl Mech Rev. 2001;54:503-524. Available from: https://doi.org/10.1115/1. 1420194.

2. Doyle JF. A wavelet deconvolution method for impact force identification. Exp Mech. 1997;37:403-408. Available from: https://doi.org/10.1007/BF02317305.

3. Inoue H, Yokoyama S, Kishimoto K, Shibuya T. Inverse analysis of impact force using the wavelet transform. Proc International Symposium on Inverse Problems in Engineering Mechanics. Nagano, Japan. 2001;p. 100-103.

4. Lifschitz LA, D'Attellis CE. Input force reconstruction using wavelets with application to a pulsed plasma thruster. Math Comput Model. 2005;41:361-369. Available from: https://doi. org/10.1016/j.mcm.2004.11.001.

5. Li Z, Feng Z, Chu F. A load identification method based on wavelet multi-resolution analysis. J Sound Vib. 2014;33(2):381391. Available from: https://doi.org/10.1016/j.jsv.2013.09.026.

6. Tran $\mathrm{H}$, Inoue $\mathrm{H}$. Impact force reconstruction using wavelet deconvolution technique. ASEAN Engineering Journal (AEJ). 2018;8(1):53-66.

7. Tran $\mathrm{H}$, Inoue $\mathrm{H}$. Development of wavelet deconvolution technique for impact force reconstruction: Application to reconstruction of impact force acting on a load-cell. Int J Impact Eng. 2018;122:137-147. Available from: https://doi.org/10.1016/j. ijimpeng.2018.07.020.

8. Wu E, Tsai TD, Yen CS. Two methods for determining impactforce history on elastic plates. Exp Mech. 1995;35(1):11-18. Available from: https://doi.org/10.1007/BF02325828.

9. Daubechies I. Ten lectures on wavelets. SIAM, Philadelphia, USA. 1992;PMID: 18296155. Available from: https://doi.org/10. $1137 / 1.9781611970104$. 

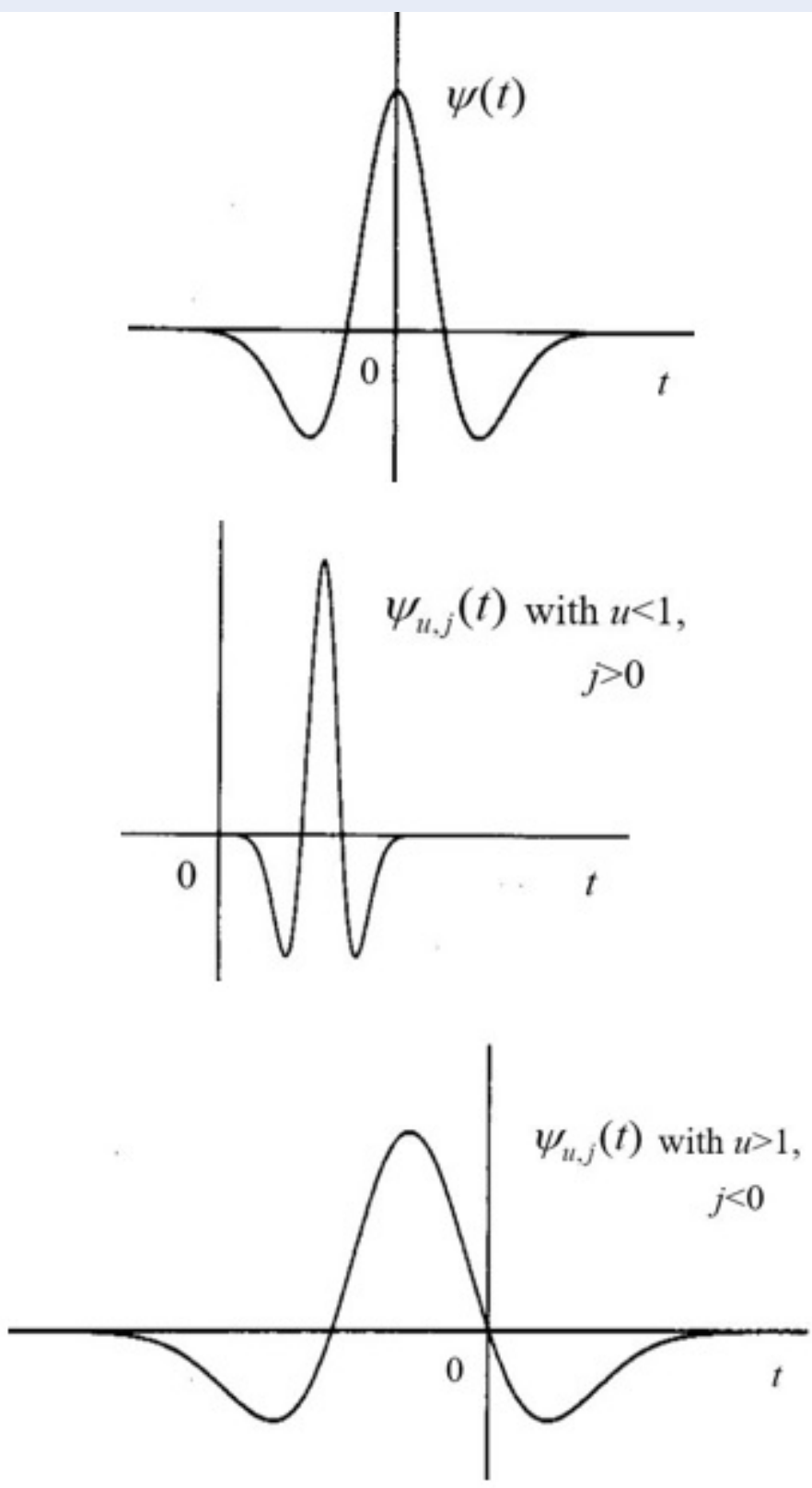

Figure 5: Typical shapes of wavelets $\psi_{u, j}(t)$ that are all copies of the same function by a dilated (stretched or compressed) and translated versions of $\psi(t)^{9}$. 


\section{Kỹ thuật tái thiết lực va chạm bằng phương pháp nghịch đảo sử dụng biến đổi wavelets: nghịch đảo tích chập tương hỗ}

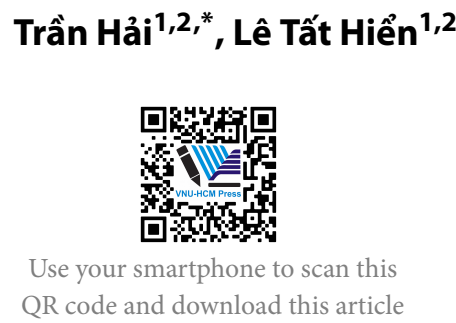

${ }^{1}$ Trường Đại học Bách Khoa Thành phố Hồ Chí Minh, Việt Nam

${ }^{2} Đ a ̣ i$ học Quốc gia Thành phố Hồ Chí Minh, Việt Nam

Liên hệ

Trần Hải, Trường Đại học Bách Khoa Thành phố Hồ Chí Minh, Việt Nam

Đại học Quốc gia Thành phố Hồ Chí Minh, Việt Nam

Email: haitran@hcmut.edu.vn

Lịch sử

- Ngày nhận: 19-7-2019

- Ngày chấp nhận: 30-12-2020

- Ngày đăng: 11-02-2021

DOI : 10.32508/stdjet.v3iSI2.507

\section{Check for updates}

\section{Bản quyền}

๑ ĐHQG Tp.HCM. Đây là bài báo công bố mở được phát hành theo các điều khoản của the Creative Commons Attribution 4.0 International license.

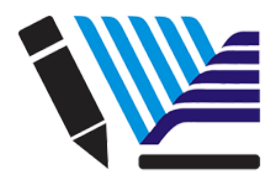

VNU-HCM Press

\section{TÓM TẮT}

Trong lĩnh vự kỹ thuật va chạm, một trong những vấn đề được quan tâm nhất là làm sao biết được chính xác lịch sử của lực va chạm tác động lên kết cấu, việc xác định lực va chạm này thường gặp khó khăn và thường không thể bằng cách đo trực tiếp. Trong thực tế, thông tin vể lực va chạm tác dụng lên kết cấu có thể được xác định gián tiếp bằng việc sử dụng thông tin đáp ứng đầu ra tương ứng được đo đạc trên kết cấu. Cụ thể là bằng cách sử dụng đáp ứng đầu ra tương ứng (gây ra bởi lực va chạm chưa biết) như gia tốc, chuyển vị, biến dạng,..., kết hợp với hàm đáp ứng xung của hệ va chạm, thì đồ thị của lực va chạm có thể được tái xây dựng lại. Một phương pháp không trực tiếp như vậy để xác định lực va chạm thường được biết đến như là kỹ thuật tái thiết lực va chạm (impact force reconstruction technique) hay kỹ thuật tính nghịch đảo tích chập lực va chạm (impact force deconvolution technique). Không may thay, một kỹ thuật nghịch đảo tích chập đởn giản để tái thiết lực va chạm thường gặp trở ngại do bản chất suy yếu của việc nghịch đảo. Do vậy, kỹ thuật nghịch đảo tích chập thường dẫn đến các kết quả tái thiết lực va chạm không mong muốn do các sai số nhỏ không thể tránh khỏi trong các đáp ứng đầu bị khuếch đại thành giá trị rất lớn trong kết quả của lực được tái thiết. Chính sự khuếch đại lớn này của các sai số sẽ lấn át làm hư hại đồ thị lực va chạm mà chúng ta mong muốn. Mặc dù đã có nhiều phương pháp chuẩn hóa nhằm làm giam bản chất suy yếu của bài toán nghịch đảo, tuy nhiên các giải pháp này thường được ứng dụng cho toàn bộ dữ liệu của quá trình va chạm. Cách áp dụng các phương pháp chuẩn hóa như thế này thường không hiệu quả do lực va chạm trong thực tế thường bị giới hạn trong một khoảng thời gian va chạm nhất định. Bài báo này phát triển một kỹ thuật tái thiết mới với việc sử dụng chuyển đổi wavelet. Dựa trên những ưu điểm của chuyển đổi wavelet như biểu diễn toàn dữ liệu thông qua các tỉ lệ (scales) và dịch chuyển (shifts) của duy nhất một loại wavelet ban đầu (mother wavelet), hữu hạn trong miền thời gian, phương pháp nghịch đảo tích chập tương hỗ (mutual deconvolution) cho việc tái thiết lực va chạm sẽ được đưa ra dưới sự cân nhắc các tî lệ khác nhau của wavelets. Kỹ thuật tái thiết được đưa ra trong bài báo này sẽ được kiểm nghiệm thực tế bằng thí nghiệm. Kết quả thí nghiệm cho thấy kỹ thuật được trình bày trong nghiên cứu này là hữu hiệu khi có thể tái thiết chính xác hơn và ổn định hơn lịch sử của lực va chạm.

Từ khoá: Chuyển đổi wavelet, Lực va chạm, Nghịch đảo tích chập, Tính toán nghịch đảo, Tái thiết lự va chạm
Trích dẫn bài báo này: Hải T, Hiển L T. Kỹ thuật tái thiết lực va chạm bằng phương pháp nghịch đảo sử dụng biến đổi wavelets: nghịch đảo tích chập tương hỗ. Sci. Tech. Dev. J. - Eng. Tech.; 3(SI2):SI60- 